Journal of Energy and
Environmental Sustainability
Journal homepage : www.jees.in

\title{
Investigation of Performance and Emissions of 10\% n-Butanol/ Diesel Blend in an IDICI Engine
}

\author{
Mritunjay Shukla ${ }^{a, b}$, Kalyan Singh $^{a}$, Gaurav Tripathi ${ }^{\mathrm{b}}$, Atul Dhar ${ }^{* b}$ and OP Sharma ${ }^{a}$ \\ andian Institute of Petroleum, Dehradun \\ ${ }^{b}$ School of Engineering, Indian Institute of Technology Mandi, Mandi
}

\section{A R T I C L E I N F O}

Received : 09 May 2017

Revised : 05 June 2017

Accepted : 09 June 2017

Keywords:

biofuel, butanol, wear, engine emissions

\begin{abstract}
A B S T R A C T
$\mathrm{CI}$ engines are preferred worldwide in heavy hauling for their efficiency and torque. But, these engines are known for their notorious NOx and black smoke emissions. Newer emission norms all around the globe have put limits on the emission of nitrogen oxides and particulate matter, in an attempt to curb these hazardous emissions of CI engines. This paper explores the use of $10 \% \mathrm{n}$-butanol/diesel blend in CI engine in order to reduce emissions and effect on engineperformance is also studied. The study focuses on BSFC, BTE, Brake Power (BP), fuel injection equipment wear, $\mathrm{NOx}$, smoke opacity, $\mathrm{CO}_{2}$ emissions characteristics of butanol-diesel blend. Experimental results show that use of butanol-diesel blend in $\mathrm{CI}$ engine effectively reduces the $\mathrm{NOx}$, smoke and $\mathrm{CO}_{2}$ emissions. Another key trend observed was reduction of $\mathrm{BTE}$ and $\mathrm{BP}$ with slight increase in $\mathrm{BSFC}$.
\end{abstract}

\section{Introduction}

Worldwide research is going on renewable and clean fuels for IC engines. Alcohols and biodiesels can be used partially or fully in compression ignition (CI) engines without much modification. Alcohols and biodiesels are also helpful in emission reduction, fuel economy and life cycle restrain on $\mathrm{CO}_{2}$ emissions [Siwale et al., 2013; Rakopoulos et al., 2006]. Generally, ethanol is used with diesel because it has better solubility in diesel. Butanol, which is also miscible with diesel can solve the problem of fuel instability at lower temperature. It is found that butanol containing blend has comparable fuel property to diesel compared to ethanol-dieselblend [Chotwichien et al., 2009]. There is serious reduction in smoke while $\mathrm{NO}$ emission increases in turbo charged diesel engine operated with biodiesel blend orn-butanol blend compared to baseline diesel fuel [Rakopoulos et al., 2010].

It is important to note that partial premixed compression ignition combustion of N-butanol blend effectively reduces soot mass in comparison to diesel fuel and has little influence on particulate matter size distribution [Cheng et al., 2016]. Biodiesel-ethanol-diesel three component fuel system was used in diesel engine to investigate the effect of load and ethanol amount variation on engine emissions. With increase in ethanol amount, $\mathrm{CO}$ emission increased and $\mathrm{NO}_{x}$ emission decreased. Over $50 \%$ load, HC emission decreases for high ethanol amount while above $70 \%$ load HC emission decreases for all ethanol concentration [Yilmaz et al., 2014].Kwanchareonet al. reported that with decrease in temperature, solubility of biodiesel in ethanol-diesel decreases. Mixture of $80 \%$ diesel, $15 \%$ biodiesel and $5 \%$ ethanol has high Cetane index and resulted in reduced emissions [Kwanchareon et al., 2007]. Yilmaz et al. compared various blends of diesel-biodiesel, biodiesel-alcohol and biodiesel-alcoholsvegetable oil on the basis of emissions and performance characteristics. Results showed that diesel-biodiesel blends has less $\mathrm{CO}$ and $\mathrm{HC}$ emissions and high NO emissionsin comparison to diesel-biodiesel-alcohol blend and diesel-biodiesel-alcohol-vegetable oil blend [Yilmaz et al., 2014].Sahin et al. comparedn-butanol/diesel belnds(nB) and n-butanol fumigation (nBF).They reported that smoke is reduced by use of both n-butanol/ diesel blend and n-butanol fumigation. But fumigation method reduces more smoke than blending method [Sahin et al., 2015]. Investigation in a turbo-charged engine indicated that engine performance characteristics and $\mathrm{NO}$ emission improves for lower blends [Sahin et al., 2015]. Combustion analysis and heat release analysis of diesel fuel blend with either ethanol ( 5 and $10 \%$ by volume) or $n$-butanol ( 8 and $16 \%$ by volume) shows that ignition delay is increased and maximum cylinder pressure and temperature are slightly reduced. Smoke opacity and $\mathrm{NO}_{x}$ emission is reduced with blending and reduction continues with increase in blending percentage [Rakopoulos et al., 2011]. Diesel fuel blended with n-butanol $(5,10,15$ and $20 \%$ by volume) result in decrease in

* Corresponding Author: add@iitmandi.ac.in 
smoke opacity, nitrogen oxides and carbon monoxides and increase in hydrocarbon emission. Brake specific fuel consumption and brake thermal efficiency increased while exhaust gas temperature decreased with nbutanol blending compared to mineral diesel [Dogan et al., 2011].

Three different blends of butanol/diesel $(8 / 92,16 / 84$ and $24 / 76$ by volume) were used by Rakopoulos et al. to determine emissions and performance characteristics in direct injection high speed diesel engine. They reported that $\mathrm{CO}$ emission, $\mathrm{NO}_{\mathrm{x}}$ emission and smoke density reducesand this reduction continues with higher blend ratio of butanol. While HC emission increase with butanol/diesel blending. From performance point of view there is increase in specific fuel consumption, brake thermal efficiency and exhaust gas temperature and same trend isobserved with high speed diesel engine and blend of ethanol with diesel fuel with 5, 10 and $15 \%$ by volume [Rakopoulos et al., 2007, Rakopoulos et al., 2010.,Rakopoulos et al., 2010]. Zhang et al. studied the effect of blending B20 (20\% biodiesel and $80 \%$ diesel) with $5 \%, 10 \%$ and $15 \%$ of butanol by volume. They reported that by butanol addition, particulate matter concentrations and number decreases while the organic carbon concentration increases. The geometric mean diameter of the particles decreases. There is decrease in particle-phase polycyclic aromatic hydrocarbons, carcinogenic potential and cytotoxicity of particle extracts with butanol addition [Zhang et al., 2014]. Yilmaz et al. investigated the performance and emissions characteristics of butanol blended biodiesel fueled indirect injection diesel engine. Results showed reduction in exhaust gas temperatures and nitrogen oxides emissions while increase in carbonmonoxide and unburned hydrocarbons. The biodiesel with $20 \%$ butanol blend results in high CO and HC emissions and low NOx emission than conventional fuel [Yilmaz et al., 2014].

In this study pre combustion chamber heating (indirect injection) technique is used along with varying load and speed conditions for butanoldiesel blend to investigate the effect on engine performance and emissions. Studies of other authors mentioned above regarding use of butanol-diesel blends are related investigation in direct injection engines without precombustion chambers. Novel aspect of this study, which is comparing the performance of butanol blends in pre-combustion chamber engine is one way of dealing with the problem of poor evaporation characteristics of alcohols. Alcohols are considered very prone to cause the wear so this study also focuses on wear of fuel injection equipment (FIE).

\section{Materials and Methods}

\subsection{Fuel Properties:}

Various physico-chemical properties of these blends were determined by adopting standard methods.It can be observed that blending of butanol in diesel results in reduction of Cetane number, viscosity and density (table 1). Observed reduction in pour point temperature will be helpful in improving the performance of engine at low temperature. Absence of phase separation confirmed the stability of butanol-diesel blending.

Gravity separation method, centrifuge testing and sub zero cooling for low temperature stability were used for testing the stability of the fuel blends. Absence of phase separation confirmed the stability of butanol-
Table 1: Comparison of important properties of diesel and butanoldiesel blends

\begin{tabular}{l|l|l|l}
\hline $\begin{array}{l}\text { S. } \\
\text { No. }\end{array}$ & Property & Diesel & $\begin{array}{l}\text { Bu10+ } \\
\text { diesel }\end{array}$ \\
\hline 1 & CN & 51.6 & 46.0 \\
2 & Density (g/cc) at $15^{\circ} \mathrm{C}$ & 0.8334 & 0.8225 \\
3 & Kinematic Viscosity $\left(\mathrm{mm}^{2} / \mathrm{s}\right)$ at $40^{\circ} \mathrm{C}$ & 3.18 & 2.50 \\
4 & Calorific Value $(\mathrm{MJ} / \mathrm{kg})$ & 43.4 & 42.5 \\
5 & CCI & 54.2 & 51.8 \\
6 & Pour point ${ }^{\circ} \mathrm{C}$ & -3 & -6 \\
7 & Sediment $(\mathrm{mg} / 100 \mathrm{ml})$ & 0.3 & 0.05 \\
8 & Sulphur $(\mathrm{ppm})$ & 481.7 & 457.8 \\
9 & Water $(\mathrm{ppm})$ & 59 & 174 \\
10 & Cetane index & 53.2 & 51.8 \\
11 & Sulphur content $(\mathrm{ppm})$ & 481.7 & 457.8 \\
\hline
\end{tabular}

diesel blending. Butanol can be mixed with diesel or diesel fuel in any proportion without phase separation. Compared to ethanol, butanol can be mixed in higher ratios with diesel for use in existing cars without the need for retrofit as the air-fuel ratio and energy content are closer to that of diesel.

\subsection{Engine Experimental Setup:}

In this study experiments were performed on four stroke, four cylinder indirect injection, water cooled diesel engine used for passenger cars (TATA Indica V2, TATA Motors). Engine specificationsare presented in Table 2. The engine is coupled with chassis dynamometer to measure engine torque (figure 1). Computer control of dynamometer control unit was used to record the engine speed and torque.The fuel consumption was measured with a gravimetric fuel flow meter (AVL, Austria). Air consumption was measured with a laminar flow element (Meriam LFE, USA). HORIBA automotive emission analyzer MEXA-584L was used to measure the concentration levels of $\mathrm{HC}, \mathrm{CO}_{2}$ and $\mathrm{NOx}$. Smoke opacity was measured by using AVL 437 smokemeter. The test cycle undergone was in accordance with BIS specifications. Test fuels weretested at 2000 to $5000 \mathrm{rpm}$ engine speed and 50 to $100 \%$ engine load.

Table 2 Specification of test engine

\begin{tabular}{|l|l|}
\hline Type & $\begin{array}{l}475 \text { IDI with Microprocessor based } \\
\text { Engine Management System (ECU) }\end{array}$ \\
\hline No. of cylinder & 4 inline \\
Piston displacement & $1405 \mathrm{cc}$ \\
Maximum output & $53.5 \mathrm{PS} @ 5500 \mathrm{rpm}$ \\
Maximum Torque & $8.5 \mathrm{~kg}-\mathrm{m} @ 2500 \mathrm{rpm}$ \\
Compression Ratio & $22: 1$ \\
\hline
\end{tabular}

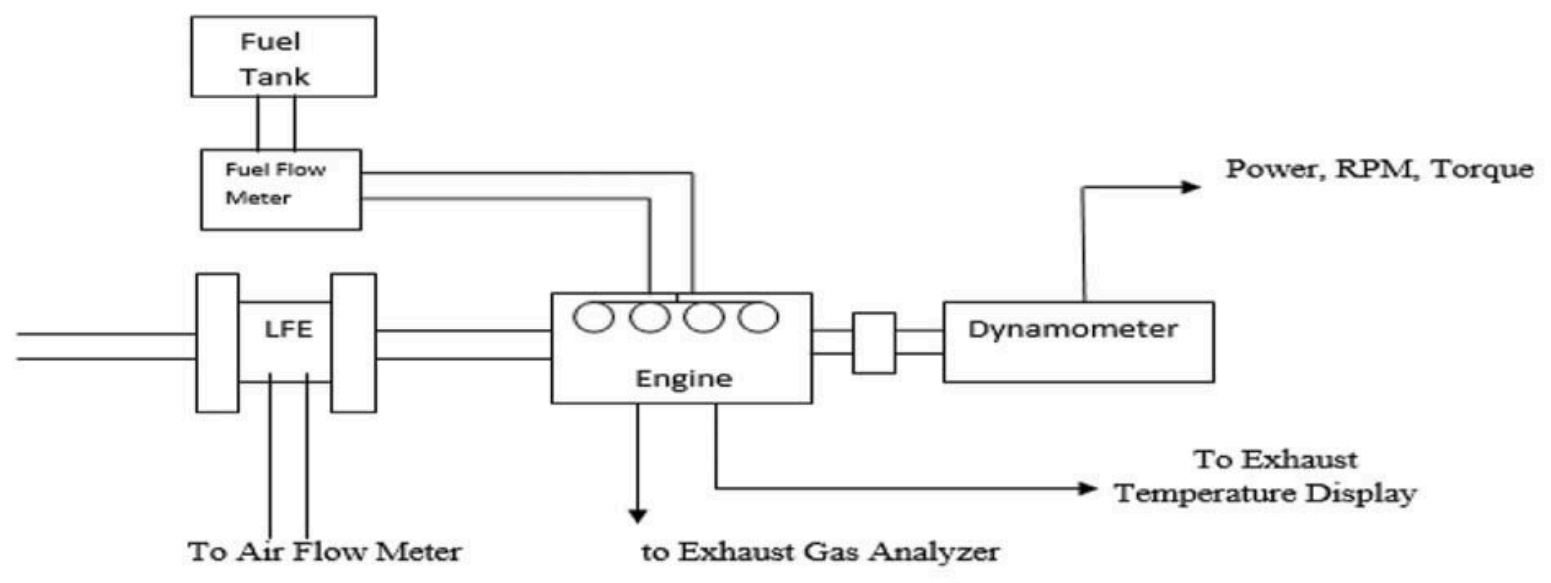

Figure 1. Layout of experimental setup 


\section{Results and Discussion}

\subsection{Distillation curve and wear and friction characteristics:}

Complete distillation is not obtained ( $99 \mathrm{vol} \%$ distillated) with the mixture contains residue $(0.5 \%)$ and loss $(0.5 \%)$. At higher distillation fractions of both fuels the required temperature becomes almost same (figure 2a). The High Frequency Reciprocating Rig (HFRR) method has been used to determine the lubricity characteristics of both fuels. This method also provides information about coefficient of friction and film percentage formed during friction test (figure 2b, 2c). ASTM D6079 standard is followed during fuel lubricity test. HFRR result shows that coefficient of friction of butanol-diesel blend is higher than diesel fuel, which indicates that diesel fuel has more lubricity in comparison to butanoldiesel blend. Film percentage in butanol-diesel blend case is lower than diesel fuel.

HFRR result shows that the average wear scar diameter of butanoldiesel blend is $396 \mu \mathrm{m}$ which is higher than the wear scar diameter of diesel fuel that has range of $391.5 \mu \mathrm{m}$. This difference in wear scar diameter indicates towards small reduction in fuel lubricity with addition of butanol.

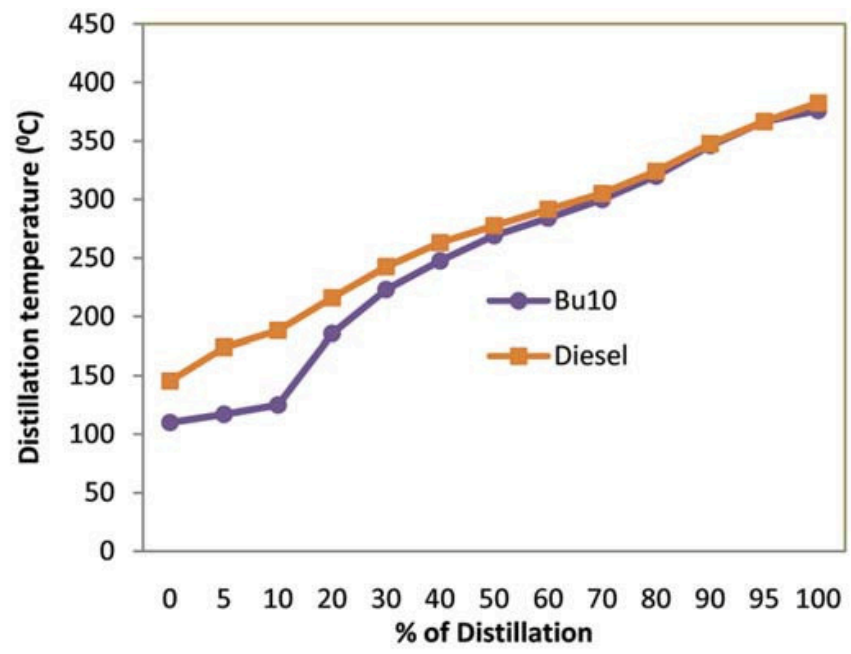

Figure 2a. Distillation curve of diesel and butanol-diesel blend

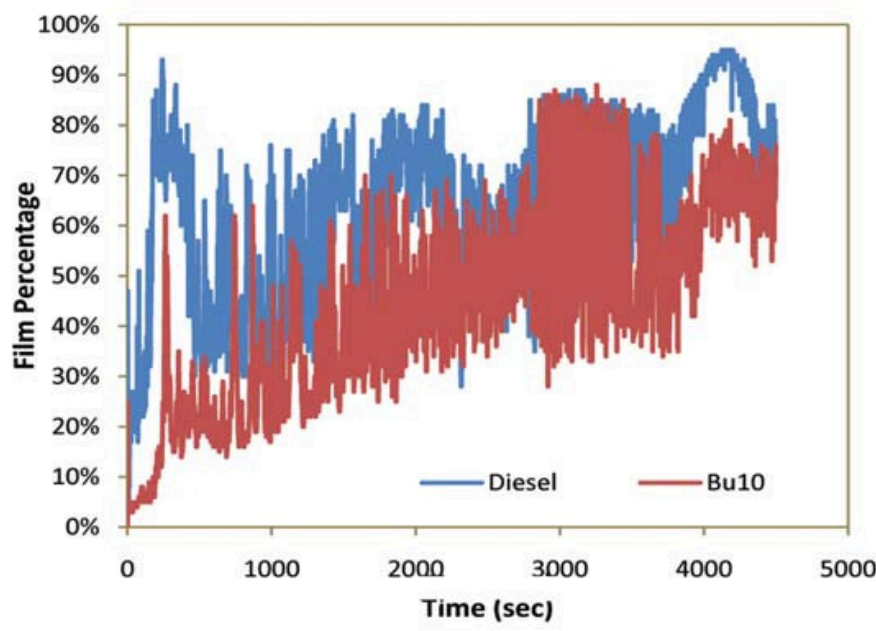

Figure 2b Film thickness tribological characteristics of mineral diesel and diesel-butanol blend

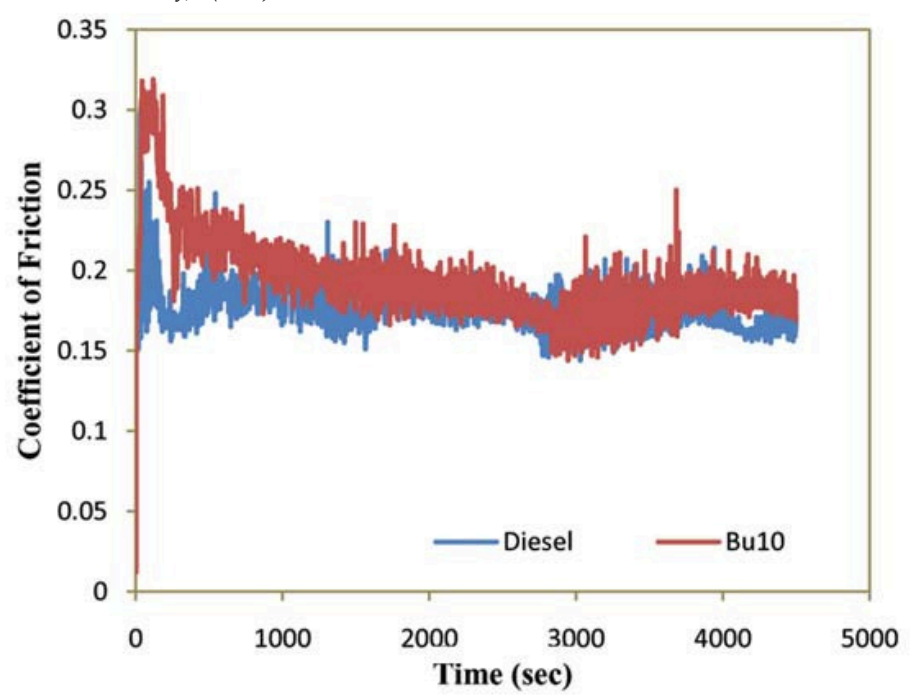

Figure 2c. Coefficient of friction tribological characteristics of mineral diesel and diesel-butanol blend

\subsection{Brake power and torque output:}

The variation of torque output and brake power output drawn for nbutanol/diesel blend for different engine speeds (figure 3 ). The maximum torque is obtained at $3000 \mathrm{rpm}$ with diesel fuel at full load. Maximum torque value is reduce by $3.5 \%$ when butanol is blend with diesel. The average torque values are decrease approximately by $3.7 \%$ compare to diesel fuel at full load. Maximum brake power obtained at $5000 \mathrm{rpm}$ with diesel fuel at full load. Brake power output decreased with butanol addition. The reduction in brake power and torque output is attributed to lower energy content of butanol than conventional diesel. Same trend of brake power and torque was also obtained for $\mathrm{n}$-butanol/diesel blend with turbocharged direct injection diesel engine by Siwale et al. (Siwale et. al., 2013).

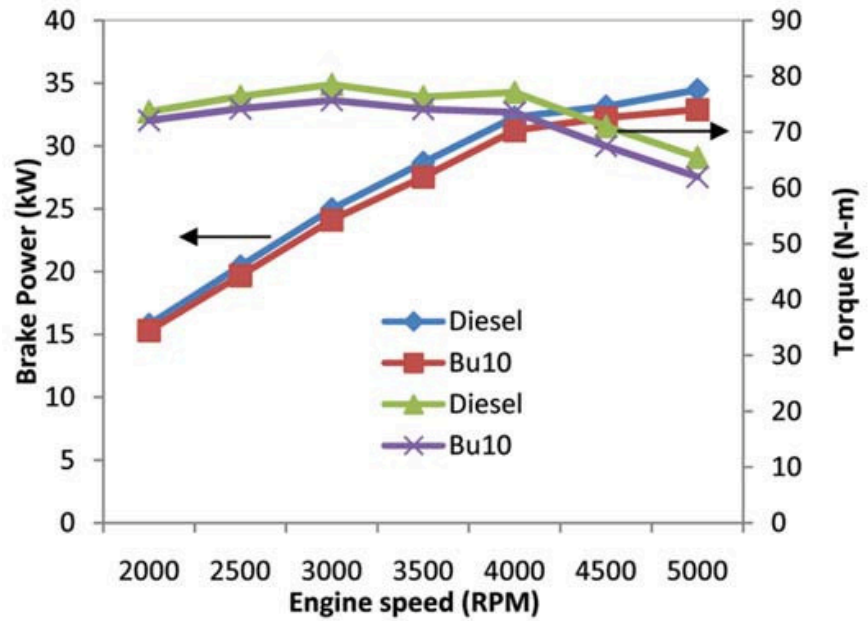

Figure3. Torque output and Brake power output versus engine speed at full load

\subsection{Brake specific fuel consumption (BSFC) and brake thermal efficiency (BTE):}

The BSFC variation with engine speed for butanol-diesel blend at different load conditions are drawn (figure 4a). The highest BSFC observed at $50 \%$ load for $10 \%$ butanol-diesel blend and lowest BSFC is obtained for diesel for all engine speeds. There is average 3.4\% increase in BSFC at full load $10 \%$ butanol-diesel blend. Other researchers also reported increase in BSFC by use of n-butanol/diesel blend in CI engine (Dogan, 2011). This increase in fuel consumption is occurring because of lower calorific value of butanol. 
Brake thermal efficiency was calculated and drawn for various loads at different speeds for $10 \%$ butanol-diesel blend (figure $4 \mathrm{~b}$ ). BTE increases with load while decreases with speed. Butanol addition lead to approximately $5.4 \%$ average reduction in BTE at full load. Butanol has higher latent heat of evaporation than diesel, which causes decrease in combustion temperature and results in reduced BTE and increase BSFC. Fushimi et al. also observed reduction in BTE on addition of bio-butanol in diesel fuel (Fushimi et. al., 2013).

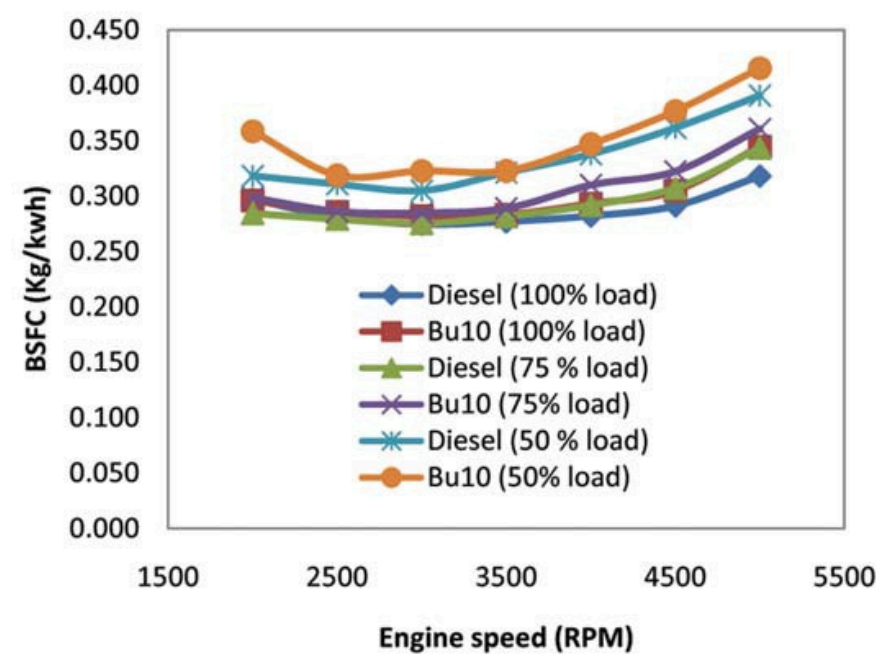

Figure4a. Comparison of BSFC values for test fuels

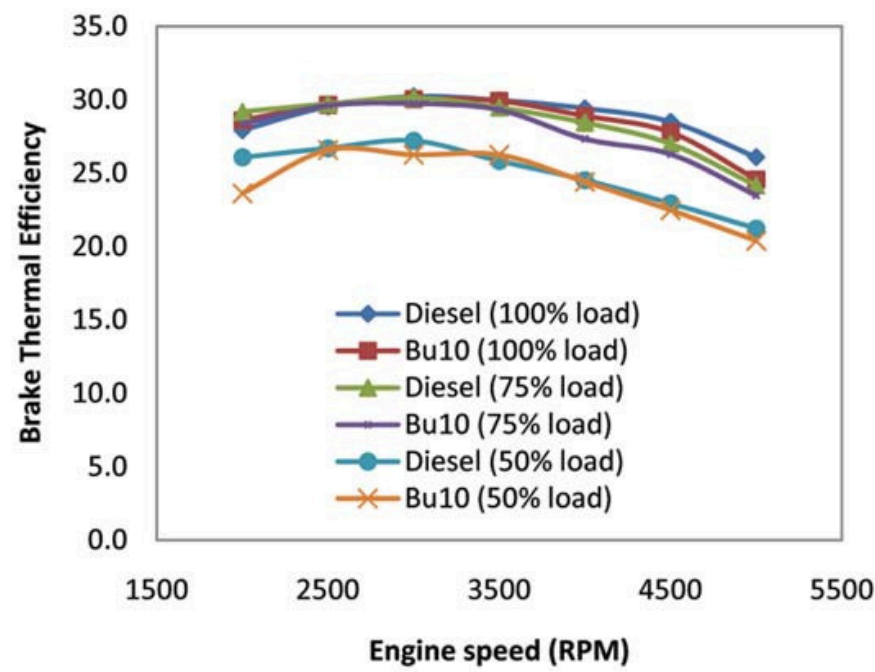

Figure4b. Brake thermal efficiency comparison for various load

\section{$3.4 \mathrm{CO}_{2}$ emission:}

Figure 5 shows the variation of $\mathrm{CO}_{2}$ for butanol/diesel blend for various loads and speed. Butanol addition to diesel fuel increases $\mathrm{CO}_{2}$ emission at lower load but at higher load $\mathrm{CO}_{2}$ emission decreases with butanol addition. Reduction in peak power with butanol addition at full load results in decrease in $\mathrm{CO}_{2}$ concentration in the exhaust at full load. Reduction in brake thermal efficiency at lower load results in increased $\mathrm{CO}_{2}$ concentration in exhaust at lower loads with butanol addition. As discussed above, butanol production is from various plant sources. And it is general fact that plant absorbs $\mathrm{CO}_{2}$ for their growth. Hence, butanol combustion does not add any extra $\mathrm{CO}_{2}$ emission [Chen et al., 2012].

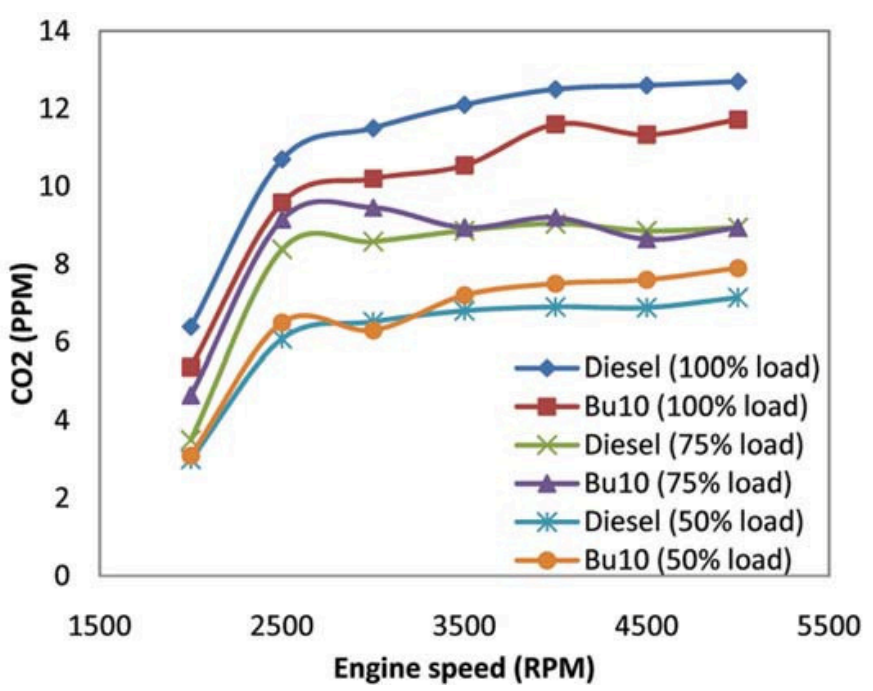

Figure 5. Comparison of $\mathrm{CO}_{2}$ emission for test fuels

\subsection{NO emissions and Smoke opacity:}

The variation of $\mathrm{NO}$ emission for different fuels at with engine speed and load is shown in figure 6a. There is decrease in NO value with butanol supplementation in diesel. NO formation is mainly depend on combustion temperature and flame temperature [Atmanlý et al., 2013].Higher latent heat of butanol causes more reduction in temperature while evaporating the fuel causing a decrease in temperature of combustion chamber. Reduction in temperature results in $\mathrm{NO}$ emission reduction. Altun et al. also reported reduction in NOx on addition of butanol in dieselbiodiesel blend (Altunet. Al., 2011).

Figure $6 \mathrm{~b}$ shows variation of smoke opacity for butanol-diesel blend at different load and speed. It is noticed that smoke opacity emission is higher for diesel fuel in comparison to butanol-diesel blend. By use of butanol-diesel blend, there is $20.13 \%$ reduction in smoke opacity compare to diesel fuel at full load. Butanol contains fuel bound oxygen contrary to diesel, which results in decreasing the smoke by increasing constituent oxygen available in n-butanol/diesel blends. Other researchers also reported that smoke opacity decreases with addition of butanol [Lujaji et al., 2011, Yosimoto et al., 2001, Yosimoto et al., 2002].

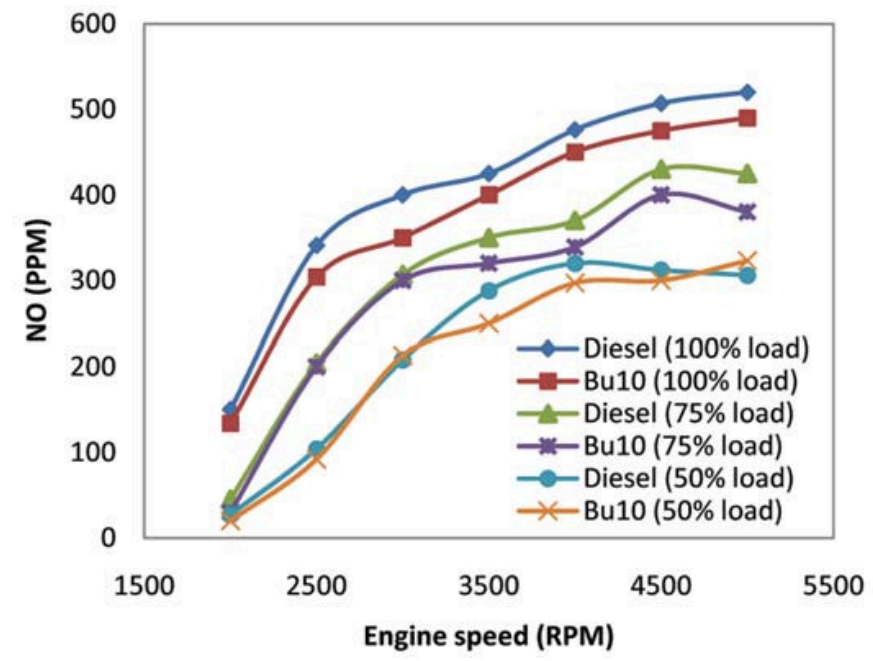

Figure6a. Comparison of NO emissions for the test fuels 


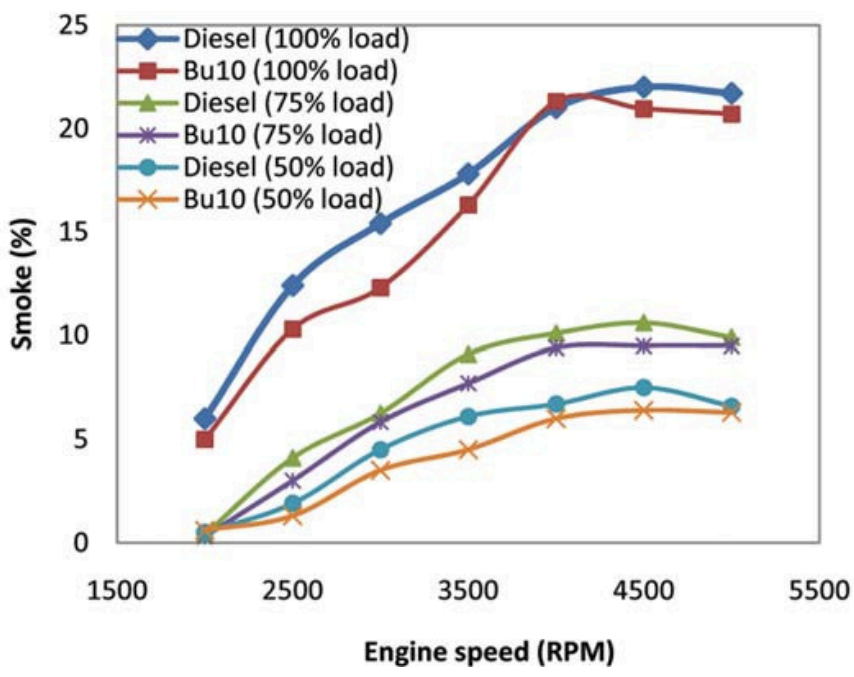

Figure 6b. Comparison of smoke opacity of the test fuels

\section{Conclusions}

The physical properties of butanol/diesel blend such as density, viscosity, cetane index and sulphur content were comparable with diesel according to fuel property tests. The engine performance test shows that the power output and torque output of engine reduced when butanol is added to diesel fuel.The exhaust emissions test showed that NO emission and smoke opacity is decreased with butanol addition.

Finally, it can be concluded that butanol can be used as promising additive to diesel in IDCI engine, which will help in improvement in exhaust emissions.

\section{References:}

[1]. Altun S, Oner C, Yasar F, Adin H. Effect of n-butanol blending with a blends of diesel and biodiesel on performance and exhaust emissions of a diesel engine. Ind. Eng. Chem. Res. 2011, 50, 9425-9430.

[2]. Atmanlý A, Yuksel B, Ileri E. Experimental investigation of the effect of dieselcotton oil-n-butanol ternary blends on phase stability, engine performance and exhaust emission parameters in a diesel engine. Fuel 2013; 109:503-11.

[3]. Cheng X, Li S, Yang J, Liu B.Investigation into partially premixed combustion fueled withN-butanol-diesel blends. Renewable Energy 86 (2016) 723-732.

[4]. Chen G, Yu W, Li Q, Huang Z. Effects of n-butanol addition on the performanceand emissions of a turbocharged common-rail diesel engine. SAE Tech Pap N2012-0108522012.

[5]. Chotwichien A, Luengnaruemitchai A, Jai-In S. Utilization of palm oil alkyl esters as an additive in ethanol-dieselandbutanol-diesel blends. Fuel 88 (2009) 1618 1624 .

[6]. Dogan O. The influence of n-butanol/diesel fuel blends utilization on a small diesel engine performance and emissions. Fuel 90 (2011) 2467-2472.

[7]. Fushimi K, Kinoshita E, Yoshimoto Y. Effect of butanol isomer on diesel combustion characteristics of butanol/gas oil blend. SAE 2013-32-9097.
[8]. Kwanchareon P, Luengnaruemitchai A, Jai-In S. Solubility of a diesel-biodieselethanol blend, its fuel properties, and its emission characteristics from diesel engine. Fuel 86 (2007) 1053-1061.

[9]. Lujaji F, Kristof L, Bereczky A, Mbarawa M. Experimental investigation of fuel properties, engine performance, combustion and emissions of blends containing croton oil, butanol, and diesel on a CI engine. Fuel 201 1;90(2):505-10.

[10]. Rakopoulos CD, Dimaratos AM, Giakoumis EG, Rakopoulos DC. Investigating the emissions during acceleration of a turbocharged diesel engine operating with bio-diesel or n-butanol diesel fuel blends. Energy 35 (2010) 5173-5184.

[11]. Rakopoulos CD, Antonopoulos KA, Rakopoulos DC, Hountalas DT, Giakoumis EG. Comparative performance and emissions study of a direct injection diesel engine using blends of diesel fuel with vegetable oils or bio-diesels of various origins. Energy Convers Manage 2006;47:3272-87.

[12]. Rakopoulos DC, Rakopoulos CD, Papagiannakis RG, Kyritsis DC.Combustion heat release analysis of ethanol or n-butanol diesel fuel blends in heavy-duty DI diesel engine. Fuel 90 (2011) 1855-1867.

[13]. Rakopoulos CD, Antonopoulos KA, Rakopoulos DC. Experimental heat release analysis and emissions of a HSDI diesel engine fueled with ethanol-diesel fuel blends. Energy 32 (2007) 1791-1808.

[14]. Rakopoulos DC, Rakopoulos CD, Giakoumis EG, Dimaratos AM, Kyritsis DC. Effects of butanol-diesel fuel blends on the performance and emissionsof a highspeed DI diesel engine. Energy Conversion and Management 51 (2010) 19891997.

[15]. Rakopoulos DC, Rakopoulos CD, Hountalas DT, Kakaras EC, GiakoumisEG,Papagiannakis RG. Investigation of the performance and emissions of bus engine operating on butanol/diesel fuel blends. Fuel 89 (2010) 2781-2790.

[16]. Sahin Z, Durgun O, Aksu ON. Experimental investigation of n-butanol/diesel fuel blends and n-butanol fumigation - Evaluation of engine performance, exhaust emissions, heat release and flammability analysis. Energy Conversion and Management 103 (2015) 778-789.

[17]. Sahin Z, Aksu ON. Experimental investigation of the effects of using low ratio nbutanol/diesel fuel blends on engine performance and exhaust emissions in a turbocharged DI diesel engine. Renewable Energy 77 (2015) 279-290.

[18]. Sittichaitaweekul Y. "Fuel properties and the treatment of vegetable oil for the use in a diesel engine". M.S. thesis, Dept. Chem. Eng., Suranaree University of Technology, Nakhon Ratchasrima, Thailand, 2003.

[19]. Siwale L, Kristof L, Adam T, Bereczky A, et al. Combustion and emission characteristics of n-butanol/diesel fuel blend in a turbo-charged compression ignition engine. Fuel 2013; 107:409-18.

[20]. Siwale L, Kristof L, Adam T, Bereczky A, et al. Performance characteristics of nbutanol-diesel fuel blend fried in a turbo charged compression ignition engine. JPEE 2013; 1, 77-83.

[21]. Weerachanchai P, Tangsathitkulchai $C$, and Tangsathitkulchai M. Phase behaviors and fuel properties of bio-oil-diesel-alcohol blends. International Journal of Chemical, Molecular, Nuclear, Materials and Metallurgical Engineering Vol:3, No:8, 2009. World Academy of Science, Engineering and Technology

[22]. Yilmaz N, Vigil FM, Donaldson AB, Darabseh T. Investigation of CI engine emissions in biodiesel-ethanol-diesel blendsas a function of ethanol concentration. Fuel 115 (2014) 790-793.

[23]. Yilmaz N, Vigil FM. Potential use of a blend of diesel, biodiesel, alcohols and vegetable oil in compression ignition engines. Fuel 124 (2014) 168-172.

[24]. Yilmaz N, Vigil FM, Benalil K, Davis SM, Calva A. Effect of biodiesel-butanol fuel blends on emissions and performance characteristics of a diesel engine, Fuel 135 (2014) 46-50.

[25]. Yosimoto Y, Onodera M, Tamaki H. Performance and emission characteristics of a diesel engine fueled by vegetable oils. SAE Paper No. 2001-01-1807/4227.

[26]. Yosimoto Y, Onodera M. Performance of a diesel engine fueled by rapeseed oil blended with oxygenated organic compounds. SAE Paper No. 2002-01-2854.

[27]. Zhang ZH, Balasubramanian R. Influence of butanol addition to diesel-biodiesel blend on engine performance and particulate emissions of a stationary diesel engine.Applied Energy 119 (2014) 530-536. 